\title{
Why I . . . sing
}

\section{Internal medicine and endocrinology specialist Milla Rosengård-Bärlund tells Adrian O'Dowd why singing in a group is the perfect way to forget about work and socialise}

\section{Adrian O’Dowd}

London, UK

Singing is a childhood hobby carried on into adult life that offers a great escape from work stress for Milla Rosengård-Bärlund.

Her busy work life at the Helsinki University Hospital in Finland is made all the more enjoyable by the singing group she helped form.

"Singing is the perfect way to forget about work,"

Rosengård-Bärlund says. "It promotes wellbeing and is a social thing. There's a lot of research showing an association between choir singing and better physical and mental health. Also, doing something together, face-to-face, is even more important today, when most of our interactions are done remotely through social media."

Finland has a long musical tradition, Rosengård-Bärlund says, and she started singing and playing instruments when she was six years old. "I have been singing in different choirs all my life."

While at medical school at the University of Helsinki, Rosengård-Bärlund met likeminded students who were also keen singers.

An a cappella ensemble called fiveAlive was founded in 1997 and Rosengård-Bärlund is its musical director. The group consists of an endocrinologist, nephrologist, paediatrician, and residents in internal medicine and plastic surgery-all working at Helsinki University Hospital—as well as a general practitioner.

The appeal is obvious, she says. "I love singing because it's a way to express your feelings and a way to forget about work, studies, or any problems. When singing in a group, you're working together in collaboration and connecting with the audience."

The group meets a couple of times a month-or more often if they have a performance coming up. "We have around 10 performances a year-often related to the medical profession, such as performing at congress or meeting evening events," Rosengård-Bärlund says.

The group has had particular success with a song they wrote two years ago called Sote Con Chaos, which is about longstanding social welfare and healthcare reform in Finland, the so-called "Sote reform."

The lyrics were written to mark the opening ceremony of the Finnish Medical Convention, a high profile event attended by the then minister of social affairs and health, Juha Rehula.

The performances can also sometimes lead to other doctors approaching them for advice on how they might do something similar.

Even with a busy career, finding time to sing isn't difficult, Rosengård-Bärlund says. "My husband isn't a doctor but he also sings in a choir so I get a lot of understanding from him. It's important to realise that physicians need some time free from work and to have fun.

"I always find the time because I enjoy it. I can be stressed when I go to rehearsals, but I always feel happy and relaxed afterwards."

\section{How to make the change}

- Don't assume that you aren't good enough to be in a choir-there are many different types and not all of them perform difficult pieces

- Attending events where they have a "come along and sing" night, rather than being in a formal choir, is a good way to start

- Find a conductor who will lead you

- Initially keep your group small—around five or six people.

Watch fiveAlive perform Sote Con Chaos at www.youtube.com/watch?v=Vxl_ 8pgDS5M

Published by the BMJ Publishing Group Limited. For permission to use (where not already granted under a licence) please go to http://group.bmj.com/group/rights-licensing/ permissions 